\title{
Demographic structure of Caryophyllaceae Juss. rare species coenopopulations in Uzbekistan
}

\author{
Khabibullo Shomurodov ${ }^{1 *}$, Ozodbek Abduraimov ${ }^{1}$, Nodira Rakhimova ${ }^{1}$, Vasila \\ Sharipova ${ }^{1}$ and Rizamat Khayitov ${ }^{2}$ \\ ${ }^{1}$ Institute of Botany Academy of Sciences Republic of Uzbekistan Str. Durmon Yuli, 32. Tashkent, \\ Uzbekistan, 100125 \\ ${ }^{2}$ Navoi State Pedagogical Institute, Str. Ibn Sina 15, Navoi, Uzbekistan, 210100
}

\begin{abstract}
The article is devoted to the assessment state of the ontogenetic structure of some rare species of the Caryophyllaceae Juss. (Acanthophyllum cyrtostegium Vved. and Silene tomentella Schischk.), listed in the Red book of the Republic of Uzbekistan. In different ecological conditions and plant communities in the Kyzylkum desert, the studied coenopopulations are normal, but incomplete. In most cases, yang grows is absent, which indicates an irregular renewal and elimination of young individuals due to lack of soil moisture, which is often observed in desert conditions. The ontogenetic spectra of investigated coenopopulations are centered and it coincides with the theoretically established spectrum. This, in general, reflects the biological characteristics of the studied species and indicates a stable state of the examined coenopopulations.
\end{abstract}

\section{Introduction}

The genus Acanthophyllum Meyer includes about 60 species, distributed mainly in the IranTuran region with the center of diversity in North-Eastern Iran and adjacent areas of Afghanistan and Turkmenistan [1,2]. in Central Asia, the genus is represented by 30 species [3], and in the flora of Uzbekistan - 11 [4]. However, as a result of a critical analysis of herbarium materials stored in the herbarium of the Institute of Botany Academy of Sciences Republic of Uzbekistan (TASH) and data obtained during field research over the past 10 years, this list was supplemented with 3 species-Acanthophyllum pungens (Bunge) Boiss, A. stenostegium Freyn., A. subglabrum Schischk. Of these, 8 species grow in the Kyzylkum desert: A. borszczowii Litv., A. cyrtostegium Vved., A. korolkowii Regel et Schmalh., A. krascheninnikovii Schischk., A. pungens (Bunge) Boiss, A. stenostegium Freyn., A. subglabrum Schischk., A. elatius Bunge. According to many morphological characters, $A$. krascheninnikovii is similar to A. pungens, which requires a detailed study on the independence of the species. Of the 14 species distributed on the territory of Uzbekistan, 4 are endemic. A. cyrtostegium - one of the endemic of Uzbekistan is characterized by more ecological plasticity. It grows on gypsum-bearing soils (less sandy

\footnotetext{
* Corresponding author: h.shomurodov@mail.ru
} 
sediments) of the foothill plains of Kyzylkum desert among Artemisia diffusa formations and is often found in fissures of the outlier mountains and at the exit of variegated rocks.

The roots of some species in the above-ground organs contains many saponins. The latter is used as medicinal raw materials and raw materials for the production of detergents and foaming agents (used in perfumes, in the food industry, in medicine) [5]. They are also good fodder for camels.

The genus Silene L. is one of the largest genera in the family Caryophyllaceae. According to G. A. Lazkov [6], this genus includes only about 800 species, distributed mainly in the Ancient Mediterranean. Later, Ü. Budak and M. Koç [7] note that the number of representatives of this polymorphic genus in the World is about 700 species. Of these, almost 600 species are distributed in Eurasia. South-West and Central Asia is one of the main centers of diversity in this genus. The largest number of representatives of this genus are found in the flora of Turkey [8] and Iran [9]. In Central Asia, the genus Silene is represented by 104 species [3]. Of these, 29 are found in the flora of Uzbekistan [4], 44 species in the flora of Tajikistan [5], 61 species in the flora of Kazakhstan [10]. G. Lazkov in his monograph "Caryophyllaceae family in the flora of Kyrgyzstan" [6] notes 31 species for this Republic. Analysis of the literature data shows that experts opinions on the total number of Silene species is differ. Replenishment of this genus at the expense of new described species continues [7, 9, 11, 12]. In Central Asia, species of the genus Silene are widespread everywhere, from deserts to the alpine zone. In the latter, these are mainly rock species. Most of them grow in open areas, in steppes, semi-savannas, in meadows among sparse woody and shrubby thickets, on stony and sandy substrates and on rocks. Many annual species are weeds and ruderal plants. Silene tomentella Schischk. - the endemic of Kyzylkum desert, grows on gravel and rocky slopes and in fissures of the rocks of the outlier mountains [13]. Occurs singly or forms small groups consisting of 5-8 individuals.

\section{Materials and methods}

The objects of research were: Acanthophyllum cyrtostegium and Silene tomentella listed in the Red book of the Republic of Uzbekistan. Geobotanical descriptions were made in all communities where the population structure of species was studied, according to the generally accepted method [14]. When identifying the plant species, was used by the "Key to plants of Central Asia" [13]. Coenopopulations were described according to the classifications of A. A. Uranov and O. V. Smirnova [15], the type of coenopopulation was described according to the classification of "Delta - omega" $(\Delta-$ w) by L.A. Zhivotovsky [16].

\section{Results and discussion}

During the expeditions organized in 2018-2020 in the Kyzylkum desert, 6 coenopopulations (CP) of Acanthophyllum cyrtostegium were studied (Figure 1). The brief description of the place of growth these coenopopulations is shown in Table 1. 


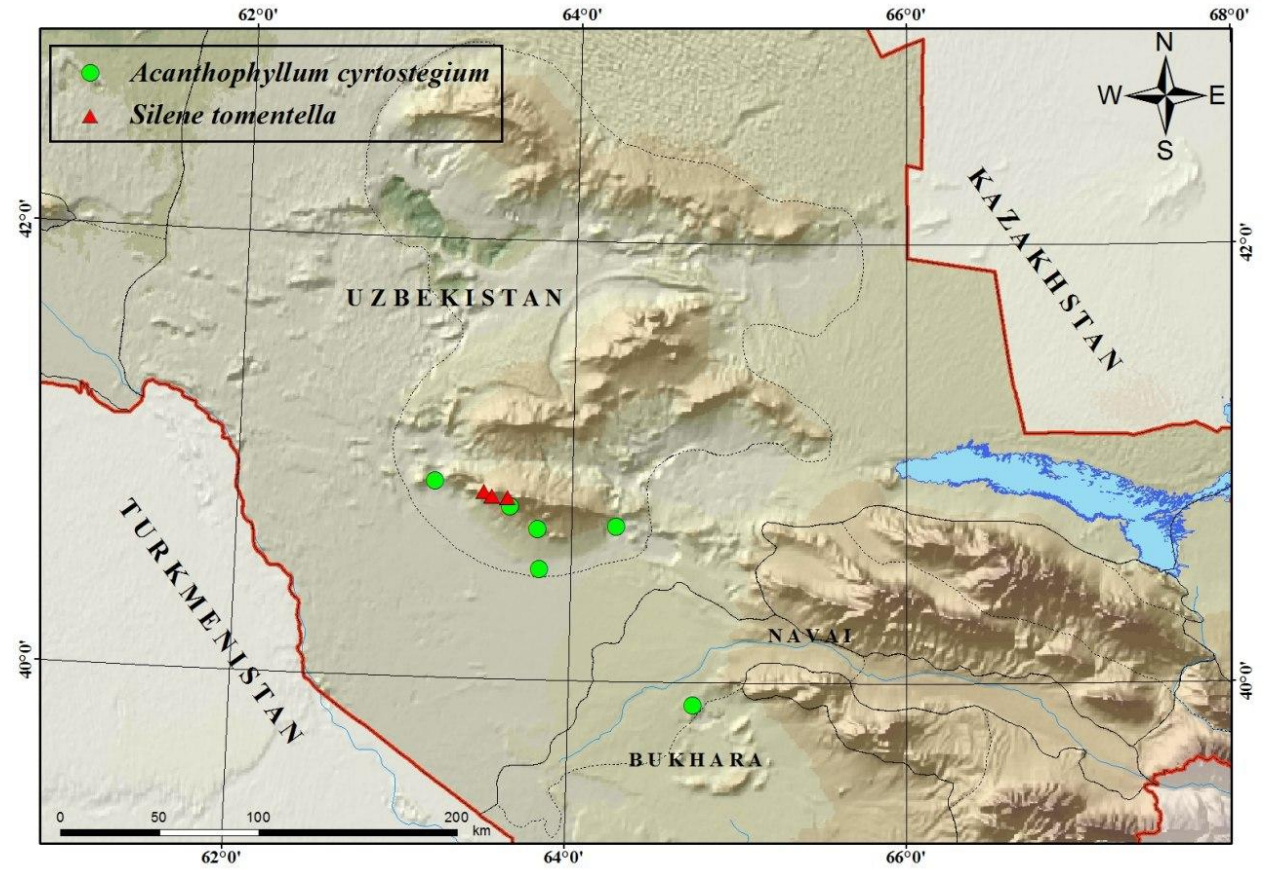

Fig.1. Map of the location studied coenopopulations

Table 1. Characteristics of plant communities

\begin{tabular}{|c|c|c|c|c|c|c|}
\hline $\begin{array}{l}\text { № } \\
\mathrm{CP}\end{array}$ & $\begin{array}{l}\text { Geographical } \\
\text { locations of } \\
\text { the CP }\end{array}$ & $\begin{array}{l}\text { Soil } \\
\text { type }\end{array}$ & $\begin{array}{l}\text { Geographic } \\
\text { coordinates, } \\
\text { altitude above } \\
\text { sea level (h) }\end{array}$ & $\begin{array}{c}\text { Plant } \\
\text { community }\end{array}$ & $\begin{array}{l}\text { Numb } \\
\text { er of } \\
\text { specie } \\
\text { s in } \\
\text { the } \\
\text { comm } \\
\text { unity }\end{array}$ & $\begin{array}{c}\text { General } \\
\text { projective } \\
\text { coverage, } \%\end{array}$ \\
\hline \multicolumn{7}{|c|}{ Acanthophyllum cyrtostegium } \\
\hline 1 & $\begin{array}{c}\text { To the East of } \\
\text { the village } \\
\text { Shuruk } \\
\text { (Shafirkan } \\
\text { district, } \\
\text { Bukhara } \\
\text { region) }\end{array}$ & $\begin{array}{l}\text { Sandy } \\
\text { loam }\end{array}$ & $\begin{array}{c}40^{0} 68^{\prime} 58^{\prime \prime} \mathrm{N} \\
63^{0} 79^{\prime} 36^{\prime \prime} \mathrm{E} \\
\mathrm{h}-309\end{array}$ & $\begin{array}{l}\text { Peganum } \\
\text { harmala }+ \\
\text { Eremurus } \\
\text { korolkowii }\end{array}$ & 36 & 20 \\
\hline 2 & $\begin{array}{l}\text { Along the } \\
\text { Turtkuduk- } \\
\text { Agitma } \\
\text { highway } \\
\text { (foothill of } \\
\text { Kingirtau, } \\
\text { Bukhara } \\
\text { region) }\end{array}$ & $\begin{array}{l}\text { Sandy } \\
\text { loam }\end{array}$ & $\begin{array}{c}40^{0} 70^{\prime} 44^{\prime \prime} \mathrm{N} \\
64^{0} 26^{\prime} 52^{\prime \prime} \mathrm{E} \\
\mathrm{h}-325\end{array}$ & $\begin{array}{c}\text { Artemisia } \\
\text { diffusa }+ \\
\text { Ferula foetida }\end{array}$ & 20 & 20 \\
\hline 3 & $\begin{array}{l}\text { Along the } \\
\text { Karakata- } \\
\text { Dzhangeldi } \\
\text { highway } \\
\text { (Romitan } \\
\text { district, }\end{array}$ & Sandy & $\begin{array}{c}40^{0} 89^{\prime} 38^{\prime \prime} \mathrm{N} \\
63^{0} 17^{\prime} 69^{\prime \prime} \mathrm{E} \\
\mathrm{h}-340\end{array}$ & $\begin{array}{c}\text { Artemisia } \\
\text { diffusa }+ \\
\text { Ferula foetida } \\
+ \text { Acanthophyl } \\
\text { lum } \\
\text { cyrtostegium }\end{array}$ & 30 & 15 \\
\hline
\end{tabular}




\begin{tabular}{|c|c|c|c|c|c|c|}
\hline & $\begin{array}{l}\text { Bukhara } \\
\text { region) }\end{array}$ & & & & & \\
\hline 4 & $\begin{array}{l}18 \text { km North } \\
\text { of the } \\
\text { Kyzylkum } \\
\text { desert station } \\
\text { along the } \\
\text { Dzhangeldi- } \\
\text { Shafirkan } \\
\text { road } \\
\text { (Shafirkan } \\
\text { district, } \\
\text { Bukhara } \\
\text { region) }\end{array}$ & $\begin{array}{l}\text { Shingl } \\
\text { e and } \\
\text { gravel } \\
\text { Pebble } \\
\text { - } \\
\text { gravel } \\
\text { ly }\end{array}$ & $\begin{array}{c}40^{0} 50^{\prime} 46^{\prime \prime} \mathrm{N} \\
63^{0} 80^{\prime} 95^{\prime \prime} \mathrm{E} \\
\text { h-373 }\end{array}$ & $\begin{array}{c}\text { Salsola } \\
\text { arbuscula }+ \\
\text { Acanthophyllu } \\
m \\
\text { cyrtostegium }+ \\
\text { Artemisia } \\
\text { diffusa }\end{array}$ & 32 & 17 \\
\hline 5 & $\begin{array}{l}2 \mathrm{~km} \text { West of } \\
\text { the village of } \\
\text { Kalata } \\
\text { (Western } \\
\text { spurs of } \\
\text { Kuldzhuktau, } \\
\text { Bukhara } \\
\text { region) }\end{array}$ & Sandy & $\begin{array}{c}40^{0} 78^{\prime} 71^{\prime \prime} \mathrm{N} \\
63^{0} 62^{\prime} 78^{\prime \prime} \mathrm{E} \\
\text { h-168 }\end{array}$ & $\begin{array}{c}\text { Haloxylon } \\
\text { persicum }+ \\
\text { Ammothamnu } \\
\text { s lehmanii }+ \\
\text { Salsola } \\
\text { arbuscula }\end{array}$ & 17 & 15 \\
\hline 6 & $\begin{array}{l}7 \mathrm{~km} \text { South of } \\
\text { the } \\
\text { Kuyumazar } \\
\text { reservoir } \\
\text { (Kogon } \\
\text { district, } \\
\text { Bukhara } \\
\text { region) }\end{array}$ & $\begin{array}{l}\text { Stony- } \\
\text { gravel } \\
\text { ly }\end{array}$ & $\begin{array}{c}39^{0} 89^{\prime} 47^{\prime \prime} \mathrm{N} \\
64^{0} 73^{\prime} 78^{\prime \prime} \mathrm{E} \\
\text { h-273 }\end{array}$ & $\begin{array}{c}\text { Convolvulus } \\
\text { korolkowii }+ \\
\text { Lagochilus } \\
\text { inebrians }\end{array}$ & 20 & 10 \\
\hline \multicolumn{7}{|c|}{ Silene tomentella } \\
\hline 1 & $\begin{array}{c}\text { On the central } \\
\text { part of } \\
\text { Mountain } \\
\text { Kuldzhuktau } \\
\text { in large- stony } \\
\text { slopes }\end{array}$ & $\begin{array}{l}\text { Large- } \\
\text { stony } \\
\text { slopes }\end{array}$ & $\begin{array}{c}40^{0} 82^{\prime} 90^{\prime \prime} \mathrm{N} \\
63^{0} 52^{\prime} 01 " \mathrm{E} \\
\text { h-540 }\end{array}$ & $\begin{array}{c}\text { Artemisia } \\
\text { diffusa }+ \\
\text { Silene } \\
\text { tomentella }\end{array}$ & 24 & 8 \\
\hline 2 & $\begin{array}{l}\text { The North- } \\
\text { eastern slope } \\
\text { of } \\
\text { Kuldzhuktau } \\
\text { near the well } \\
\text { of } \\
\text { Bashguzhumd } \\
\text { y }\end{array}$ & $\begin{array}{l}\text { Stony } \\
\text { slopes }\end{array}$ & $\begin{array}{c}40^{0} 82^{\prime} 90^{\prime \prime} \mathrm{N} \\
63^{0} 52^{\prime} 01^{\prime \prime} \mathrm{E} \\
\text { h-667 }\end{array}$ & $\begin{array}{c}\text { Rhamnus } \\
\text { sintenisii+ } \\
\text { Artemisia } \\
\text { diffusa }\end{array}$ & 20 & 20 \\
\hline 3 & $\begin{array}{c}\text { The North- } \\
\text { western slope } \\
\text { Kuldzhuktau, } \\
\text { in the vicinity } \\
\text { of the well } \\
\text { Shaydaras }\end{array}$ & $\begin{array}{c}\text { Dry } \\
\text { stony } \\
\text { slopes }\end{array}$ & $\begin{array}{c}40^{0} 82^{\prime} 52^{\prime \prime} \mathrm{N} \\
63^{0} 61^{\prime} 12^{\prime \prime} \mathrm{E} \\
\mathrm{h}-681\end{array}$ & $\begin{array}{c}\text { Salsola } \\
\text { arbuscula }+ \\
\text { Artemisia } \\
\text { diffusa }\end{array}$ & 21 & 6 \\
\hline
\end{tabular}

The first CP grows to the East of the village Shuruk (Shafirkan district, Bukhara region). Geographical coordinates: $40^{\circ} 68^{\prime} 58^{\prime \prime} \mathrm{N}$ and $63^{0} 79^{\prime} 36^{\prime \prime} \mathrm{E}$. This coenopopulation grows as part of the Peganum harmala, Eremurus korolkowii community. The relief is flat, the soil is sandy loam, and the area is broken out. The dominant species of the community 
are Eremurus korolkowii and Peganum harmala. The total projected cover of the herbage does not exceed $20 \%$, the share of the studied species in it is $1 \%$. The species composition of communities is quite rich and consists of 36 species of vascular plants, most of which are herbaceous. The second CP was studied along the Turtkuduk-Agitma highway (the foothill of Kingirtau, Bukhara region) $\left(40^{0} 70^{\prime} 44^{\prime \prime}\right.$ N, 64 $26^{\circ} 52^{\prime \prime}$ E). The vegetation cover of the region consists as part of the Artemisia diffusa, Ferula foetida community. The soil is sandy loam. The total projective coverage of the community is about $20 \%$. The botanical composition of the community consists of 20 species of flowering plants. Here along with the dominant species (Artemisia diffusa, Ferula foetida), Poa bulbosa, Convolvulus hamadae, Carex pachystylis, Peganum harmala, Koelpinia linearis and others grow. The third CP was studied along the Karakata-Dzhangeldi highway (Romitan region, Bukhara region) $\left(40^{\circ} 89^{\prime} 38^{\prime \prime} \mathrm{N}, 63^{0} 17^{\prime} 69^{\prime \prime} \mathrm{E}\right)$. This coenopopulation grows as part of the Artemisia diffusa, Ferula foetida, Acanthophyllum cyrtostegium community. The soil is sandy. The total projective coverage of the community is about $15 \%$. The botanical composition of the community consists of 30 species of flowering plants. Here, along with the dominant species (Artemisia diffusa, Ferula foetida, Acanthophyllum cyrtostegium), Astragalus villosissimus, Poa bulbosa, Convolvulus hamadae, Carex pachystylis and others grow. The next CP is described $18 \mathrm{~km}$ North of the Kyzylkum desert station along the JangeldiShafirkan road (Shafirkan district, Bukhara region) in the Salsola arbuscula, Acanthophyllum cyrtostegium, Artemisia diffusa community. Geographical coordinates of this coenopopulation: $40^{\circ} 50^{\prime} 46^{\prime \prime} \mathrm{N}$ and $63^{\circ} 80^{\prime} 95^{\prime \prime} \mathrm{E}$. The soil of the described area is shingle and gravel or pebble-gravelly. The total projected cover of the herbage is $17 \%$. The species composition of the community is relatively rich and consists of 32 species of vascular plants belonging to various biomorphs. Together with the dominant species (Salsola arbuscula, Acanthophyllum cyrtostegium, Artemisia diffusa) Astragalus ammotrophus, Ferula foetida, Cousinia hamadae, Astragalus villosisimus and others grow. The fifth CP grows $2 \mathrm{~km}$ west of the village of Kalata (Western spurs of Kuldzhuktau, Bukhara region) as a part of the Haloxylon persicum, Ammothamnus lehmanii, Salsola arbuscula community $\left(40^{0} 78^{\prime} 71^{\prime \prime} \mathrm{N}, 63^{\circ} 62^{\prime} 78^{\prime \prime} \mathrm{E}\right)$. The soil is sandy. The total projected cover of the herbage reaches $15 \%$. There are 17 species registered in this community. Along with the dominant species (Ammothamnus lehmanii, Haloxylon persicum, Salsola arbuscula) grows Astragalus villosissimus, Carex physodes, Acanthophyllum cyrtostegium and etc. The sixth $\mathrm{CP}$ is grows as a part of the Convolvulus korolkowii, Lagochilus inebrians community on 7 $\mathrm{km}$ South of the Kuyumazar water reservoir in Kogon district, Bukhara region $\left(39^{0} 89^{\prime} 47^{\prime \prime}\right.$ $\left.\mathrm{N}, 64^{0} 73^{\prime} 78^{\prime \prime} \mathrm{E}\right)$. The soil in this region is stony-gravel. The total projective cover of the grass stand is $10 \%$. The botanical composition of communities consists of 20 species. The dominant species are Convolvulus korolkowii and Lagochilus inebrians.

Modern literature does not have data on the ontogenesis and state of coenopopulations of $A$. cyrtostegium. Based on the analysis of materials collected during the expeditions, the demographic structure of 6 cenopopulations of A. cyrtostegium was established. All the studied coenopopulations belong to the centered type, which reflects the characteristic ontogenetic spectrum of this species. Centered spectrum, according to L.B. Zaugolnova [17], is formed in shrubby plants with a large prolongation of life of individuals in the middle-aged ontogenetic state, the least of their elimination and difficult germination of seeds [18]. In all the studied coenopopulations, a significantly high proportion of mature generative individuals was observed in comparison with others, that is, they make up more than $50 \%$ of the total number of individuals (Table 2 ). This is primarily due to the longer generative period. 
Table 2. Distribution of individuals by age group

\begin{tabular}{|c|c|c|c|c|c|c|c|}
\hline \multirow{2}{*}{ № } & \multicolumn{7}{|c|}{ Age structure, \% } \\
\cline { 2 - 8 } & \multicolumn{7}{|c|}{ Acanthophyllum cyrtostegium } \\
\cline { 2 - 8 } & $j$ & im & $v$ & $g 1$ & $g 2$ & $g 3$ & $s$ \\
\hline 1 & 10 & 13.3 & 23.3 & 13.3 & 33.3 & 3.33 & 0 \\
\hline 2 & 0 & 8.10 & 16.21 & 18.91 & 29.72 & 16.21 & 10.81 \\
\hline 3 & 0 & 5.55 & 16.6 & 16.6 & 44.4 & 11.1 & 5.55 \\
\hline 4 & 0 & 0 & 17.24 & 13.79 & 48.27 & 6.89 & 6.89 \\
\hline 5 & 13.04 & 8.69 & 13.04 & 15.21 & 32.60 & 13.04 & 4.34 \\
\hline 6 & 0 & 0 & 20 & 6.66 & 40 & 13.3 & 20 \\
\hline \multicolumn{7}{|c|}{ Silene tomentella } \\
\hline 1 & 10.63 & 8.51 & 12.76 & 19,14 & 31,91 & 10,63 & 6.38 \\
\hline 2 & 0 & 7.69 & 30.76 & 11,53 & 34,61 & 15,38 & 0 \\
\hline 3 & 13.46 & 7.69 & 13.46 & 23,07 & 26,92 & 11,53 & 3.84 \\
\hline
\end{tabular}

Along with generative plants, there was a stable distribution of virginal individuals, which is also likely due to the longer duration of this age state compared to other age states on the left side of the spectrum. Almost all the studied coenopopulations grow in an area of intensive grazing, where there is no systematic use of pastures for a long time. In these parts of Kyzylkum, pastures are used all year round and the pasture load is two or more times higher than the permissible one. The absence of young individuals in most of the studied coenopopulations is the result of this type of anthropogenic activity. A small proportion of senile fractions in coenopopulations are characteristic of semi-desert shrubs. The largest number of senile individuals was observed in 6 CP (Figure 2).

The density of individuals in coenopopulations contributes to the analysis of their longterm dynamics. In the studied coenopopulations, the total density and ecological density of individuals were analyzed. It was found that in $1 \mathrm{~m}^{2}$ of the area the density of individuals is $0.75-1.85$, and the ecological density is $0.88-2.05$ (Table 3). The largest number of individuals and, accordingly, the highest density was observed in the fifth coenopopulation, common among the Haloxylon persicum, and its lowest value was noted in the sixth coenopopulation, growing in the zone of recreation and intensive grazing. Evaluation of the age $(\Delta)$ and efficiency $(\omega)$ of coenopopulations showed that the 1 and 5 CPs are ripening, 2 and 6 CPs are transitional, and 3 and 4 CPs are mature. 

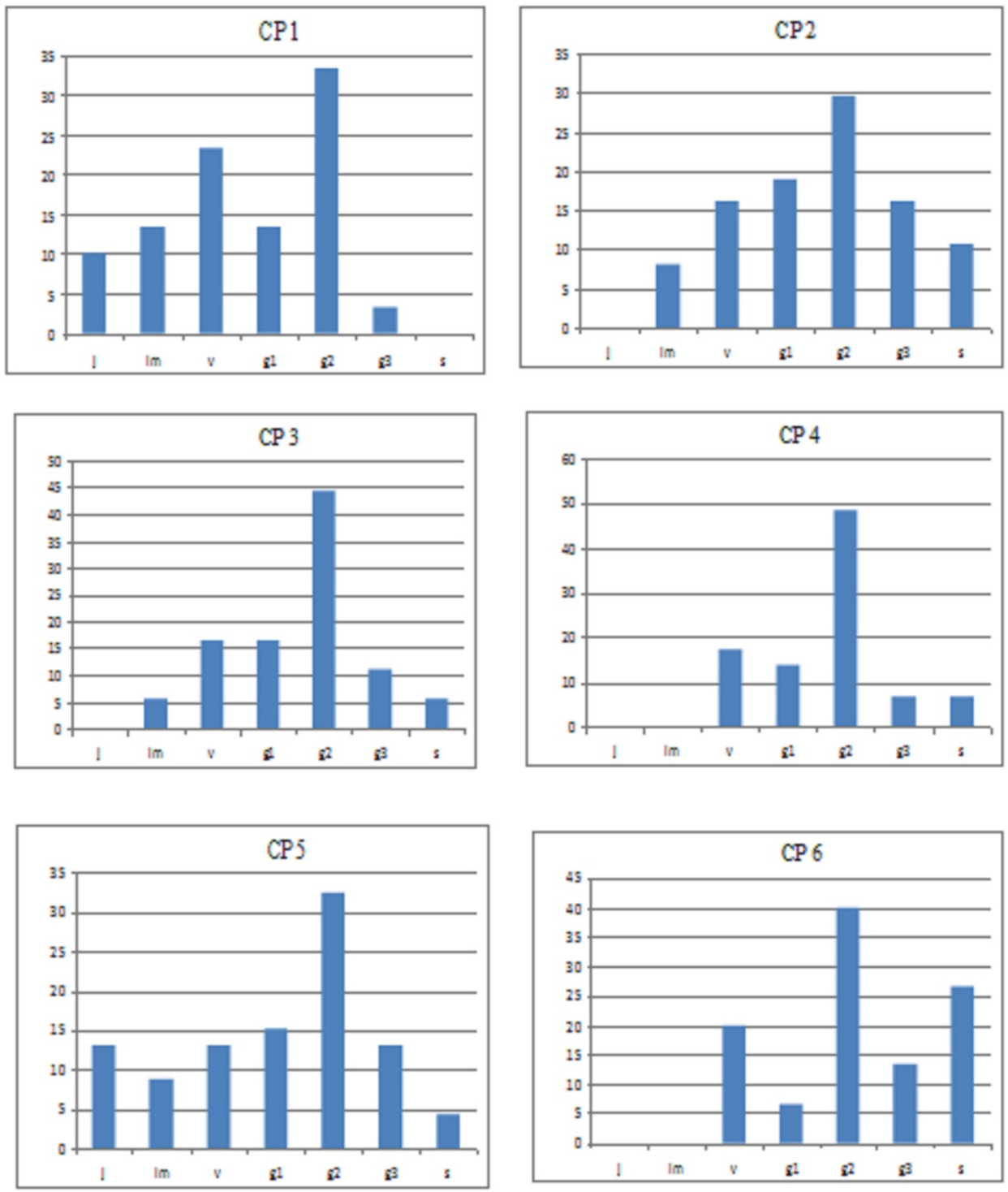

Fig.2. The ontogenetic structure of coenopopulations Acanthophyllum cyrtostegium

A characteristic feature of this community is the presence of some mountain floristic elements, such as Anemone petiolulosa, Elaeosticta vvedenskyi, Ranunculus sewerzowii, etc. Coenopopulation grows at the exit of parent rocks (in cracks). The projected coverage of the herbage reaches $20 \%$. The Botanical composition consists of 20 species. The most common are Salsola arbuscula, Poa bulbosa, Carex pachystylis, Ferula karelinii. CP 3 was studied on the North-Western dry stony slope of Kuldzhuktau ( $\left.40^{0} 82^{\prime} 52^{\prime \prime} \mathrm{N}, 63^{0} 61^{\prime} 12^{\prime \prime} \mathrm{E}\right)$, in the vicinity of the well Shaidaras in the Salsola arbuscula, Artemisia diffusa community. The plant community is dominated by Salsola arbuscula and Artemisia diffusa. Poa bulbosa, Tulipa buhseana, Ixilarion tataricum, and others are found in less abundance. At the time of the study, the total projected cover of the herbage was $6 \%$. The Botanical composition of the community consisted of 20 species. 
Table 3. Demographic characteristics of the studied coenopopulations

\begin{tabular}{|c|c|c|c|c|c|c|}
\hline № & $\begin{array}{c}\text { Total } \\
\text { number } \\
\text { of } \\
\text { individua } \\
\text { ls } \\
\text { (pieces) }\end{array}$ & $\begin{array}{c}\text { Density of } \\
\text { individual } \\
\mathrm{s} / \mathrm{m}^{2} \\
\text { (pieces) }\end{array}$ & $\begin{array}{c}\text { Ecological } \\
\text { density of } \\
\text { individuals } \\
/ \mathrm{m}^{2} \text { (pieces) }\end{array}$ & $\begin{array}{l}\text { Performance } \\
\text { index }(\omega)\end{array}$ & $\begin{array}{c}\text { Age } \\
\text { index } \\
(\Delta)\end{array}$ & CP types \\
\hline \multicolumn{7}{|c|}{ Acanthophyllum cyrtostegium } \\
\hline 1 & 29 & 1.45 & 1.70 & 0.61 & 0.27 & ripening \\
\hline 2 & 37 & 1.85 & 2.05 & 0.67 & 0.44 & transitional \\
\hline 3 & 18 & 0.9 & 1.2 & 0.75 & 0.42 & mature \\
\hline 4 & 29 & 1.45 & 1.81 & 0.74 & 0.48 & mature \\
\hline 5 & 46 & 2.3 & 2.70 & 0.63 & 0.36 & ripening \\
\hline 6 & 15 & 0.75 & 0.88 & 0.62 & 0.55 & transitional \\
\hline \multicolumn{7}{|c|}{ Silene tomentella } \\
\hline 1 & 47 & 2.35 & 2.76 & 0.64 & 0.37 & transitional \\
\hline 2 & 26 & 1.30 & 1.73 & 0.70 & 0.35 & ripening \\
\hline 3 & 52 & 2.60 & 3.25 & 0.62 & 0.33 & ripening \\
\hline
\end{tabular}

The age structure of the coenopopulation of $S$. tomentella has not been studied before. According to the classification of A.A. Uranov and O.V. Smirnova [15], the studied coenopopulation of this species is normal, but incomplete (Table 2).

The age ranges of the examined coenopopulations coincide with the characteristic one (Figure 3).
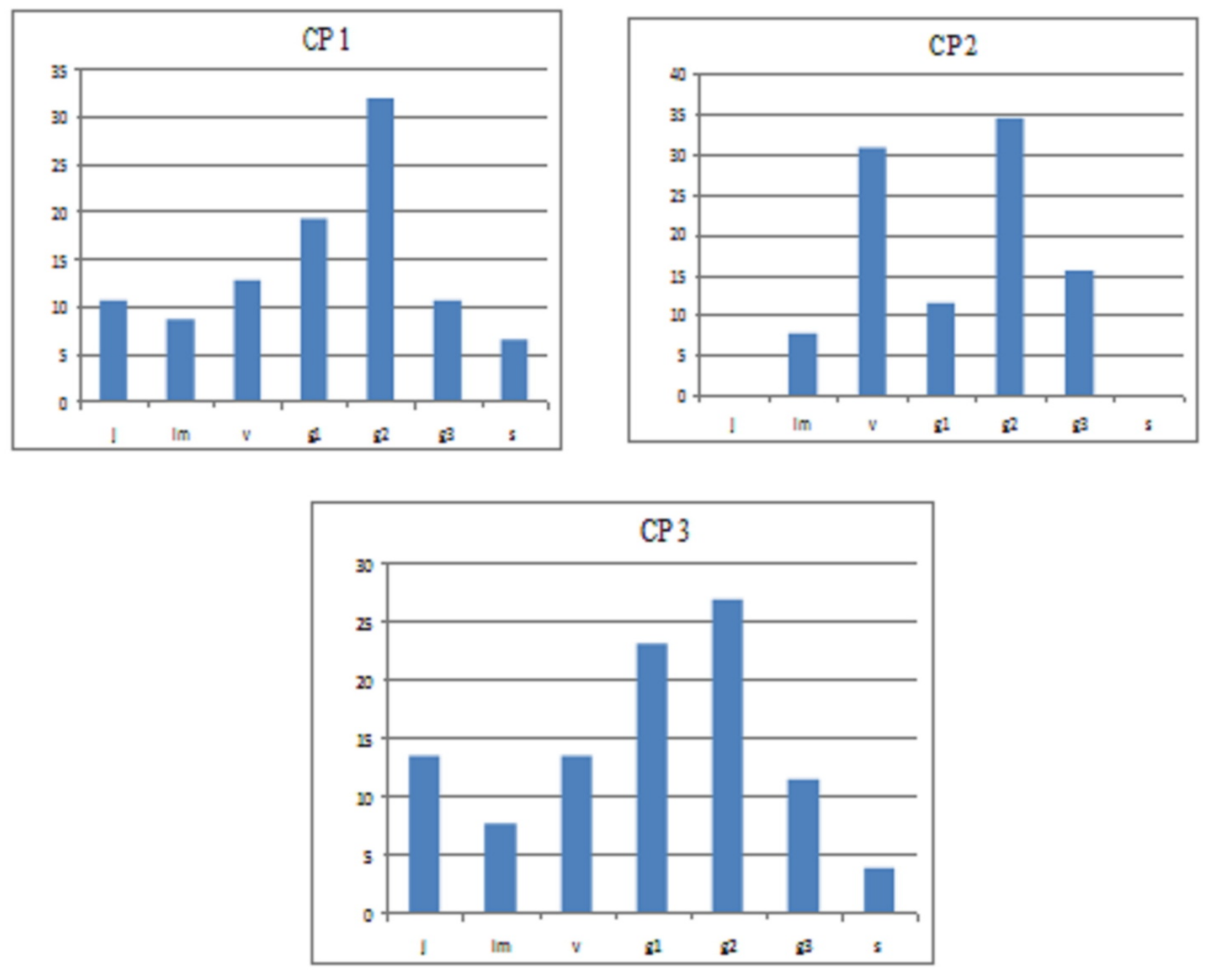

Fig.3. The ontogenetic structure of coenopopulations Silene tomentella 
They are centered with an absolute maximum on individuals of the generative state (61$64 \%$ ). The sum of individuals of pregenerative age status does not exceed $35 \%$ of the total number of plants in the coenopopulation. The abundance of pregenerative individuals in the coenopopulation indicates normal seed renewal of the species. The proportion of senile individuals does not exceed $6.38 \%$.

Analysis of the density of individuals demonstrates that the number of individuals in the studied coenopopulations does not exceed 52. The largest number of individuals were recorded on dry mountain slopes, the smallest in more moisture-rich slopes as part of tall shrubs. The total density of individuals in $1 \mathrm{~m}^{2}$ of area is $1.30-2.60$, and the ecological density of 1.73-3.25 pieces. (Table 3). According to the classification of L.B. Zhivotovsky [16], the first coenopopulation is transitional, the second and third are ripening.

\section{Conclusion}

The results of the study indicated that the coenopopulations of the studied species are normal, but incomplete. Assessment of the state of coenopopulations of Acanthophyllum cyrtostegium demonstrates that the most favorable state is the fifth coenopopulation, which grows on fixed sands as part of the Haloxylon persicum. This coenopopulation is fullfledged, the gradual increase in the number of individuals from juvenile to young generative and reaching a maximum in the mature generative state, and then a gradual decrease in their number towards prussic plants reflects the biological characteristics of the species. The coincidence of the age spectrum of this real coenopopulation with the characteristic spectrum is associated with the edaphic conditions of this area. The sandy substrate is characterized by high permeability of precipitation (this is a very important indicator for desert conditions) and retains moisture well before the onset of hot seasons. This contributes to normal growth and development, especially of young plants. The worst indicator for the age spectrum was observed in the sixth coenopopulation, where there are absent young individuals, and the share of old individuals is more than $25 \%$. This coenopopulation was studied on dislodged sections of gypsum-bearing soil in the vicinity of the Kuyumazar reservoir. This area is used for pasture all year round, the pasture load is more than twice higher than the permissible one, and this naturally leads to the depletion of the plant population. The absence of young individuals in this coenopopulation is primarily the result of trampling.

Analysis of the age spectrum of the studied Silene tomentella coenopopulations shows that the first and third coenopopulations common on the dry slopes of Kuldzhuktau are fullfledged. The gradual increase in the number of individuals from juvenile to mature age and their gradual decline to senile plants reflects the biological characteristics of the species. In the second coenopopulation, which grows in the northern, most water-rich habitats, the number of different ontogenetic groups fluctuates sharply, while both juvenile and senile individuals are absent. Such a sharp difference in the age spectrum of this CP from the previous ones is related to the ecology of the species. In the center of its ecological range, $S$. tomentella grows in cracks of dry slopes in small plant groups, where the projected cover of herbage does not exceed $6-8 \%$. The last coenopopulation grows on the Easternmost border of its range, where a lot of remnant mountain floristic elements not typical for mountains grow in the vegetation cover. The highest projection coverage and reduced lighting under a shrub of large shrubs (Rhamnus sintenisii) probably negatively affected the normal growth and development of this species.

This work was supported by the project of P3-20170919165 «Cadastre of rare and endangered species of vascular plants of the Navoi and Bukhara regions». 


\section{References}

1. A.L. Takhtajan, Floristic Regions of the World. (Berkley, 1986)

2. M. R.Joharchi, F. Memarian, A new species of Acanthophyllum (Caryophyllaceae) from Iran. Phytotaxa J. 92, 1 (2013)

3. F.O. Khassanov, Key to plants of Central Asia. Tashkent, 11 (2015)

4. Flora of Uzbekistan. Tashkent, 2 (1953)

5. Flora of Tajikistan. Leningrad, 3 (1968)

6. G.A. Lazkov, Family of Caryophyllaceae in the flora of Kyrgyzstan. (KMK, Moscow, 2006)

7. Ü. Budak, M. Koç, Silene hamzaoglui (Caryophyllaceae), a new species from Çekerek (Yozgat, Turkey). Turk. J. of Bot., 35 (2011)

8. M.J. Coode, J. Cullen, Silene L. Flora of Turkey and the East Aegean Islands. (Edinburgh, 1967)

9. A. Gholipour, Silene oxelmanii (Caryophyllaceae), a new species from Iran. Phytotaxa J. 303 (2017)

10. Flora of Kazakhstan. Alma-Ata, 3 (1960).

11. G.A. Lazkov, New genus Silene L. (Caryophyllaceae) and other novelties of the flora of Kyrgyzstan, Biological science, 4 (1991):

12. G.A. Lazkov, Two new species of the genus Silene L. (Caryophyllaceae) from TyanShan, News of systematics of vascular plants, 29 (1993)

13. Key to plants of Central Asia (Tashkent, 1968-1993).

14. Field geobotany. Ed. E.M. Lavrenko, A.A. Korchagin. Moscow-Leningrad, 3 (1964)

15. A.A. Uranov, O.V. Smirnova, Classification and basic features of the development of populations of perennial plants. Bulletin Ser. 74, 2 (1969)

16. L.A. Zhivotovsky, Ontogenetic state, effective density and classification of populations. Ecology, 2, 1 (2001)

17. L.B. Zaugolnova, O.V. Smirnova, A.S. Komarov, P.G. Hanina, Monitoring phytopopulations. J. Advances in Modern Biology, 113, 4 (1993)

18. L.A. Zhukova, Ontogenetic Atlas of Plants. Yoshkar-Ola, 7 (2013) 